Int Arch Allergy Appl Immunol 1991;95:I-V

\title{
Contents, Vol. 95, 1991
}

\section{No. 1}

Original Paper

IgG4 Autoantibodies to DNA in Systemic Lupus erythematosus Patients

Nagpal, S.; Namboodiri, M.S.A.; Subba Rao, B.S.; Subba

Rao, P.V 1

Increased Expression of FceR2/CD23 on Peripheral Blood B

Lymphocytes and Serum IgE Levels in Kawasaki Disease

Furukawa, S.; Matsubara, T.; Motohashi, T.; Sasai, K.;

Nakachi, S.; Umezawa, Y.; Yabuta, K 7

Differences in Level and Avidity of Secretory IgA Antibodies

in Breast Milk of Swedish, Indian and Japanese Mothers to

Soybean Protein

Morikawa, A.; Dahlgren, U.; Carlsson, B.; Narayanan, I.;

Hahn-Zoric, M.; Hanson, L.Å.; Maeda, S.; Tomizawa, S.;

Kuroume, T 13

Ability of Polymorphonuclear Leukocytes to Generate Active

Oxygen Species in Children with Bronchial Asthma. Use of

Chemiluminescence Probes with a Cypridina Luciferin

Analog and Luminol

Kato, M.; Nakano, M.; Morikawa, A.; Kimura, H.; Shigeta,

M.; Kuroume, T 17

Distribution of Substance P-Immunoreactive and Calcitonin

Gene-Related Peptide-Immunoreactive Nerves in Normal

Human Lungs

Komatsu, T.; Yamamoto, M.; Shimokata, K; Nagura, H. 23 A New Method of the Measurement of Nasal Secretion in

Guinea Pigs

Namimatsu, A.; Yamaura, S.; Go, K; Tanimoto, H.;

Okuda, M 29

Characterization of Methylated Bovine Serum Albumin-Induced Allergic Inflammation in Rats

Hasegawa, T.; Hirasawa, N.; Watanabe, M.; Arakawa, M.;

Tsurufuji, S.; Ohuchi, K 35

Depolarizing Action of Allergens on Passive Sensitized Lymphocytes

Kosnikov, V.V.; Dobretsov, G.E 42

Ongoing IgE Synthesis by Atopic B Cells Is Enhanced by Inter-

leukin-3 and Suppressed Directly by Interferon-Gamma in

vitro

Matsumoto, T 48 
Identification of Soybean Proteins Responsible for Respiratory Allergies

Gonzalez, R.; Zapatero, L.; Caravaca, F.; Carreira, J. . . 53 Peripheral Denervation Suppresses

the Late Phase of Delayed-

Type Hypersensitivity

Josefsson, E.; Carlsten, H.; Lange, S.; Tarkowski, A. . . 58 IgG Fc Receptors on Epithelial Cells

of Distal Tubuli and on

Endothelial Cells in Human Kidney

Aarli, A.; Matre, R.; Thunold, S 64

Inhalation Exposure of Mice to Trimellitic Anhydride Induces

Both IgG and IgE Anti-Hapten Antibody

Dearman, R.J.; Hegarty, J.M.; Kimber, 170

Regulation of Eicosanoid Generation in Activated Macro-

phages

Lim, W.H.; Stewart, A.G 77

IgE-Positive Duodenal Mast Cells in Patients with Food-Related Diarrhea

Bengtsson, U.; Rognum, T.P.; Brandtzaeg, P.; Kilander, A.;

Hansson, G.; Ahlstedt, S.; Hanson, L. $\AA \quad 86$

Short Communications

Induction of FceRП/CD23 on Human T Cells by Excretory

and Secretory Antigen of Dirofilaría immitis

Yamaoka, K.A.; Tsukidate, S.; Higaki, M.; Miyasaka, N.;

Fujita, K 92

The Effect of Systemic Treatment with Platelet-Activating

Factor on the Migration of Eosinophils to Lung, Pleural

and Peritoneal Cavities in the Guinea Pig

Colditz, I.G.; Topper, E.K 94

No. 2-3

Editorial

Releasability of Airway Macrophages in Bronchial Asthma Godard, Ph.; Damon, M.; Chanez,

P.; Michel, F.B. . .

97

Original Paper

Elucidation of the Epitope Locations of Human Autoanti-IgE:

Recognition of Two Epitopes Located within the C 22 and

the C $\varepsilon 4$ Domains

Shakib, F.; Powell-Richards, A 102

The Immune Response to Anti-Idiotype Antibodies Bearing

an Internal Image Epitope of Tetanus Toxin/Toxoid.

1. Induction of the Humoral Immune ResponsePoskitt, D.C.; Turnbull, S.; Macdonald, L.; Jean-Francois, M.J.B.; Yasmeen, D 109

The Immune Response to Anti-Idiotype Antibodies Bearing an Internal Image Epitope of

Tetanus Toxin/Toxoid.

2. Comparison of the Primary Humoral Immune Responseto Xenogeneic Ab2ß1 and Ab2ß2 Internal Image Anti-Idiotype Antibodies

Poskitt, D.C.; Turnbull, S.; Macdonald, L.; Jean-Francois,

M.J.B.; Yasmeen, D 122 
Antiasthmatic Effects of Picrorhiza kurroa: Androsin Prevents Allergen- and PAF-induced Bronchial Obstruction in Guinea Pigs

Dorsch, W.; Stuppner, H.; Wagner, H.; Gropp, M.;Demoulin, S.; Ring, J 128

IV

Contents

Influence of Mepacrine on the Reaction of Adoptive Cutaneous Anaphylaxis Bashmakov, Yu.K.; Sidorenko, T.V.; Dugovskaya, L.A. . 134

Experimental Allergic Encephalomyelitis-Prophylactic andTherapeutic Treatment with the Cyclooxygenase InhibitorPiroxicam (Feldene $\left.{ }^{\circledR}\right)$ Weber, F.; Meyermann, R.; Hempel, K 136 Selective Impairment of T Lymphocyte Activation followingContact Sensitization with OxazoloneKimber, I.; Foster, J.R.; Baker, D.; Turk, J.L 142

Histamine Stimulation of the Nasal Mucosa Does Not Induce Prostaglandin or Leukotriene Generation or Induce Me-thacholine Hyperresponsiveness Majchel, A.M.; Proud, D.; Hubbard, W.C; Naclerio, R.M. 149

Effect of a Fish Oil Diet on Asthma: Results of a 1-Year Double-Blind StudyDry, J.; Vincent, D 156

Effects of Cetirizine on Human Eosinophil and NeutrophilActivation in vitroWalsh, G.M.;

Moqbel, R.; Hartnell, A.; Kay, A.B 158

Stimulation of Human Peripheral Blood Lymphocytes withChironomid Hemoglobin Allergen (Chi 11)Liebers, V.; Schalbaba, S.; Mazur, G.; Baur, X 163

Effect of Neutral Endopeptidase Inhibition on Substance-P-Induced Increase in Short-Circuit Current of Canine Cultured Tracheal Epithelium

Tamaoki, J.; Sakai, N.; Isono, K.; Kanemura, T.; Chiyo-tani, A.; Yamauchi, F.; Takizawa, T.; Konno, K 169

Characterization of Eosinophils in a Continuous Ambulatory Peritoneal Dialysis Patient with Eosinophilic Peritonitis Sligh, J.M.; Gottlieb, S.J.; Domoto, D.T.; Slavin, R.G. . 174

Cypress (Cupressus sempervirens) Pollen Allergens: Identification by Protein Blotting and Improved Detection of Specific IgE AntibodiesFord, S.A.; Baldo, B.A.; Panzani, R.; Bass, D 178

Immunoregulation of Endometrial and Jejunal Epithelia Sensitized by InfectionCastro, G.A.; Harari, Y 184

Appearance of Macrophage Migration Inhibition Factor inPatients with Systemic Reactions to Bee VenomGoldberg, A.; Livni, E.; Mekori, Y.A 191

Bleomycin-Induced Pulmonary Fibrosis in Genetically MastCell-Deficient WBB6FrW/Wv Mice and Mechanism of theSuppressive Effect of Tranilast, an Antiallergic Drug Inhibiting Mediator Release from Mast Cells, on FibrosisMori, H.; Kawada, K.; Zhang, P.; Uesugi, Y.;

Sakamoto,0.;Koda, A 195

Antigen Dose-Dependent Regulation of Be-Memory Cell ExpressionKolbe, L.; Heusser, C;

Kölsch, E 202

Anaphylaxis Is Enhanced by Increased Absorption of Antigenin Postinfiammatory StateLevine, S.; Saltzmann, A 207

Defective Lectin-Induced p55kDa-IL2R Expression on Peripheral T Cells in Non-Hodgkin's Lymphoma PatientsHiroishi, K.; Nakanishi, K.; Yoshimoto, T.; Hada, T.;Higashino, K 212 Allergic Hepatitis in Guinea Pigs Induced by 2,4,6-Trinitro-phenyl Liver Protein ConjugateNishimoto, H.; Mori, K.; Mizoguchi, Y 221 
Survey of Hanganutziu and Deicher Antibodies in Operated

Patients

Higashihara, T.; Takeshima, T.; Anzai, M.; Tomioka, M.;

Matsumoto, K.; Nishida, K.; Kitamura, Y.; Okinaga, K.;

Naiki, M 231

Lysosomal Enzyme Activities in Experimental Granulomatous

Inflammation

Kaga, S.; Kobayashi, K.; Yamagata, N.; Takeuchi, H.T.;

Yoshida, K.; Matsuda, T.; Nakatani, K.; Kasama, T.;

Kasahara, K.; Takahashi, T 236

Bradykinin Induces Eosinophil Accumulation in the Rat Pleu-

ral Cavity

Pasquale, C.P.; Martins, M.A.; Bozza, P.T.; Suva, P.M.R.;

Castro Faria Neto, H.C.; Pires, A.L.A.; Cordeiro, R.S.B. 244 Faecally Derived Hydrolytic

Enzymes from Dermatopha-

goides pteronyssinus: Physicochemical Characterisation of

Potential Allergens

Stewart, G.A.; Lake, F.R.; Thompson, P.J 248

Interleukin-4-Induced IgG Subclass and IgE Secretion by

Mononuclear Cells from Atopic Donors

Nüsslein, H.G.; Winter, M.; Träg, T.; Kalden, J.R 257

Beta-2-Adrenoceptors of Polymorphonuclear Leukocytes in

Children with Atopic Dermatitis. Their Number and Affinity to the Radioligand [125I]-

Cyanopindolol

Pohl, A.; Otto, J.; Urbanek, R261

Comparative Antigen Analysis of Different Life Stages of

Schistosoma mansoni by Crossed Immunoelectrophoresis

Akhiani, A.A.; Nilsson, L.Å.; Ouchterlony, Ö 266

Time Course of Cellular Infiltration in the Nasal Mucosa during the Immediate Allergic Reaction

Lozewicz, S.; Gomez, E.; Chalstrey, S.; Gatland, D.;

Davies, R.J 273

Effect of Histamine on Tumor Necrosis Factor Production by

Human Monocytes

Hotermans, G.; Bury, T.; Radermecker, M.F 278

Short Communications

Interleukin-4 Gene Expression in Human Peripheral Blood

Mononuclear Cells

Mori, A.; Yamamoto, K.; Dohi, M.; Suko, M.; Okudaira, H. 282 Serum Antibody Responses in

Mice to Intermittent Inhalation

of Ovalbumin Dust

Gilmour, M.I.; Wathes, CM.; Taylor, F.G.R 285

No. 4

Original Paper

Cultures of Human Cord Blood Metachromatic Cells in Relation to Family History of Atopy,

Development of AtopicDisease, Nasal Metachromatic Cells and Perinatal FactorsBorres, M.P.;

Ahlstedt, S.; Björkstén, B 289 
Fibroblast Proliferation Factors in Pulmonary Granuloma Induced by Trichosporon cutaneum in Rabbits: Presence of aLymphocyte-Derived Fibroblast Proliferation Factor andIts Functional SpecificitySaita, N.; Ando, M.; Araki, S.; Yoshinaga, M 294

Contents

$\mathrm{V}$

Aspirin-Sensitive Asthma: Significance of the Cyclooxygenase-Inhibiting and Protein-Binding Properties of AnalgesicDrugsWilliams, W.R.; Pawlowicz, A.; Davies, B.H303

IgE-Mediated Inhalant Allergy against Human Corticotropin-Releasing HormoneKleine-Tebbe, J.; Wahl, R.; Dierks, K.; Kunkel, G 309

Immunoglobulin E in the Feces of Children and Adolescentsfrom Some Tropical and Subtropical CountriesKolmannskog, S.; Jansson, S.; Häggblom, L.; Mentzing, L.-O.; Hvidsten, D.;

Haneberg, B 316

Pharmacology of Nasal Provocation with Bradykinin: Studiesof Tachyphylaxis, Cyclooxygenase Inhibition, $\alpha$-Adren-ergic Stimulation, and Receptor SubtypeChurchill, L.; Pongracic, JA.;

Reynolds, C.J.; Naclerio, R.M.; Proud, D 322

Endogenous Regulation of Rat Brain Mast Cell Serotonin Release

Marathias, K.; Lambracht-Hall, M.; Savala, J.; Theo-harides, T.C 332

Distribution and Engraftment Patterns of Human Tonsillar Mononuclear Cells and

Immunoglobulin-Secreting Cells in Mice with Severe Combined Immunodeficiency: Role of the Epstein-Barr Virus

Nadal, D.; Albini, B.; Chen, C; Schläpfer, E.; Bernstein, J.M.; Ogra, P.L 341

Effects of the Platelet-Activating Factor Antagonist BN 52021on Anti-Islet Cytotoxicity of

Mononuclear Cells and Serumfrom Type 1 (Insulin-Dependent) Diabetic PatientsKöhler, E.;

Varnai, G.; Knospe, S.; Förster, W.; Michaelis, D.; Wanka, H 352

Identification of Reactive Synthetic Gliadin Peptides Specific for Coeliac Disease Devery, J.M.;

Bender, V.; Penttila, I.; Skerritt, J.H. ... 356

IL-4-Producing Murine T Helper Cell Line Provides Help forin vitro Production of IgEPoulsen,

L.K.; Katamura, K.; Ishizaka, K 363

Detection of Antidrug IgG Antibodies in Patients with Adverse Drug Reactions to Amodiaquine

Clarke, J.B.; Neftel, K.; Kitteringham, N.R.; Park, B.K. . 369

Human Upper Airway Epithelial Cell-Derived Granulocyte-Macrophage Colony-Stimulating

Factor Induces Hista-mine-Containing Cell Differentiation of Human Progenitor Cells

Ohtoshi, T.; Tsuda, T.; Vancheri, C; Abrams, J.S.; Gaul-die, J.; Dolovich, J.; Denburg, J.A.;

Jordana, M 376

A. Announcement 308 